\title{
Yield and fruit quality of apple from conventional and organic production systems
}

\author{
Cassandro Vidal Talamini do Amarante( ${ }^{(1)}$, Cristiano André Steffens ${ }^{(1)}$, Álvaro Luiz Mafra ${ }^{(1)}$ \\ and Jackson Adriano Albuquerque ${ }^{(1)}$
}

(1)Universidade do Estado de Santa Catarina, Centro de Ciências Agroveterinárias, Caixa Postal 281, CEP $88520-000$ Lages, SC.
E-mail: amarante@cav.udesc.br, steffens@cav.udesc.br, a2alm@cav.udesc.br, jackson@cav.udesc.br

Abstract - The objective of this study was to assess the yield and fruit quality of apple produced with a conventional and an organic production systems in Southern Brazil. The orchards consisted of alternate rows from 10 to 12-year old 'Royal Gala' and 'Fuji' apple trees on M.7 rootstocks, grown as slender spindles, on 4x6 m spacing. Eighteen apple trees of each cultivar and management system were randomly selected and assessed for nutrition, flowering, fruit set, yield, and fruit quality during two growing seasons (2002/2003 and 2003/2004). The organic management system resulted in lower concentrations of $\mathrm{K}, \mathrm{Mg}$, and $\mathrm{N}$ in leaves and fruits, and in smaller fruits for both cultivars, and lower fruit yield for 'Fuji' than from the conventional production system. For both cultivars, fruits from the organic orchard harvested at commercial maturity had a more yellowish skin background color, higher percentage of blush in the fruit skin, higher soluble solids content, higher density, higher flesh firmness, and higher severity of russet than fruits from the conventional orchard. Fruit from the organic orchard had lower titratable acidity in 'Royal Gala', and higher incidence of moldy core and lower incidence of watercore in 'Fuji', than fruit from the conventional orchard. A non-trained sensory panel detected no significant differences for fruit attributes of taste, flavor and texture between fruit from the production systems for either cultivar.

Index terms: Malus domestica, decay, fruit, physicochemical characteristics, physiological disorders.

\section{Rendimento e qualidade de maçãs em pomares conduzidos nos sistemas convencional e orgânico de produção}

\begin{abstract}
Resumo - O objetivo deste estudo foi avaliar o rendimento e a qualidade de frutos em pomares de macieira, nos sistemas convencional e orgânico de produção no Sul do Brasil. Os pomares consistiram de filas alternadas de plantas com 10 a 12 anos de idade das cultivares Royal Gala e Fuji, sobre porta-enxerto M.7, conduzidas com líder central, em espaçamento de 4x6 m. Dezoito plantas de cada cultivar e sistema de manejo foram marcadas aleatoriamente e avaliadas quanto à nutrição, floração, frutificação efetiva, rendimento e qualidade de frutos, em dois anos agrícolas (2002/2003 e 2003/2004). O sistema orgânico apresentou menores concentrações de K, Mg e $\mathrm{N}$ nas folhas e frutos, frutos de menor tamanho em ambas as cultivares e menor rendimento de frutos na cultivar Fuji. Em ambas as cultivares, frutos do pomar orgânico na maturação comercial apresentaram cor de fundo da casca mais amarelada, maior percentagem de coloração vermelha, maior teor de sólidos solúveis totais, maior densidade, maior firmeza de polpa e maior severidade de "russet" do que frutos do pomar convencional. No pomar orgânico, 'Royal Gala' apresentou a menor acidez titulável e 'Fuji' a maior incidência de podridão carpelar e menor incidência de pingo-de-mel. Não foram detectadas diferenças significativas quanto ao sabor, aroma e textura dos frutos entre sistemas de produção, em ambas as cultivares.
\end{abstract}

Termos para indexação: Malus domestica, doença, fruto, características físico-químicas, desordens fisiológicas.

\section{Introduction}

The sustainability of conventional apple production systems have been brought into question by consumers increasingly demand for apples free of chemical residues, concerns about health risks to farm workers exposure to pesticides, escalating production costs, heavy reliance on non-renewable resources, reduced biodiversity within orchards, water contamination from orchard practices, and soil degradation (Reganold et al., 2001; Peck et al., 2006; Jönsson, 2007). These concerns have lead to a great deal of interest in organic and integrated apple 
production worldwide. The organic and integrated systems had higher soil quality and potentially lower negative environmental impacts than conventional systems (Glover et al., 2000; Maluche-Baretta et al., 2006; Vogeler et al., 2006).

Organic management practices exclude the use of synthetic pesticides and fertilizers, allowing the use of animal and green manures, compost, soluble rock powders, sulfur and copper compounds, fungicidal and insecticidal soaps, botanical insecticides, traps and other biological control methods (Holb et al., 2003; Peck et al., 2006; Jönsson, 2007).

Organic apple production is still quite limited in most countries, due mainly to the inadequate control of pests and diseases with organic alternatives (Cesa et al., 2006; Jönsson, 2007) and the lack of acceptable thinning technology (McArtney \& Walker, 2004), which limits profitability of organically managed apple orchards.

The fact that a system is organic does not ensure its sustainability. To be sustainable, an orchard must produce adequate yield, be profitable, protect the environment, conserve resources and be managed in a socially responsible way. It has been claimed that organic production systems are less efficient, pose greater health risks, and typically yield less than conventional or integrated systems (McArtney \& Walker, 2004). However, Glover et al. (2000) and Reganold et al. (2001) reported environmental and economic sustainability of organic apple production systems in the state of Washington, USA. According to these authors, organic apple orchards were more labor-intensive and had higher profitability and greater energy efficiency, when compared with the conventional and integrated orchards. Reganold et al. (2001) estimated that $12-14 \%$ price premiums for fruit are required for the organic system to match the breakeven point of the conventional system, reflecting the higher costs associated with organic production. In New Zealand, organic apple production systems typically yield less than conventional or integrated ones, but market premiums for organic fruit have compensated for reduced yield (McArtney \& Walker, 2004). Lower and inconsistent yields of organic apple orchards are probably the result of unsatisfactory crop load management, higher pest and weed pressures, and nutrient deficiencies (Peck et al., 2005, 2006; Jönsson, 2007).

The major reason to choose organically grown fruit, besides the concern for environmental issues, include the perceived but so far not unequivocally proved increase in fruit quality. Several authors have compared fruit quality at harvest or after cold storage of organic, integrated, and conventional grown apples. While some authors showed no substantial differences between apples from organic and integrated orchards, in terms of fruit quality at harvest (Jönsson, 2007; Róth et al., 2007) or after cold storage (Róth et al., 2007), others have reported overall better quality of organic apples than integrated or conventional apples (DeEll \& Prange, 1992; Reganold et al., 2001; Weibel et al., 2004; Peck et al., 2006).

In 2004/2005, the Brazilian apple production corresponded to $846,400 \mathrm{Mg}$, of which the State of Santa Catarina contributed to the majority, 505,000 Mg (Epagri, 2006). Organic apple production in Brazil is incipient, despite the major increases in the organic production of agricultural commodities nationwide (25-50\% per year), with an estimate of 4,500 organic production units covering 100,000 ha (Oltramari et al., 2002).

Santa Catarina State has many small farm utilizing family and local labor. The land holding and labor supply pattern could favor the adoption of organic apple production integrated into the fruit production agribusiness in the state.

The objective of this work was evaluate yield and fruit quality of 'Royal Gala' and 'Fuji' apple trees, from orchards managed under conventional and organic production systems in Southern Brazil.

\section{Materials and Methods}

This study was carried out with apple orchards under an organic and a conventional production system, in Urupema, State of Santa Catarina, Southern Brazil $\left(28^{\circ} 17^{\prime} \mathrm{S}, 49^{\circ} 55^{\prime} \mathrm{W}\right)$, at $1,425 \mathrm{~m}$ above sea level. Climate in the region is humid mesothermic, according to the classification by Köppen, with higher precipitation from October to March, averaging $166 \mathrm{~mm}$ per month. The soil is a Haplumbrept with high values of clay $\left(530 \mathrm{~g} \mathrm{~kg}^{-1}\right)$ and organic matter $\left(65 \mathrm{~g} \mathrm{~kg}^{-1}\right)$.

The orchards under a conventional and an organic production system were planted in 1992, with alternate rows of 'Royal Gala' and 'Fuji' apple trees on M.7 rootstocks, grown as slender spindles, on a $4 \times 6 \mathrm{~m}$ spacing. The two apple orchards were located close to each other (1 km apart) so that the effect of microclimate and soil type could be reduced. Ground vegetation in both orchards was mostly grasses (Andropogon sp.) and invasive plants of the family Asteraceae. 
The area of the conventional orchard had been previously cultivated with potato. The soil was corrected with $2 \mathrm{Mg} \mathrm{ha}^{-1}$ dolomite limestone, $85 \mathrm{~kg} \mathrm{ha}^{-1}$ triple superphosphate, $500 \mathrm{~kg} \mathrm{ha}^{-1} \mathrm{KCl}$, and $30 \mathrm{~kg} \mathrm{ha}^{-1}$ borax during the orchard development process. During both growing seasons (2002/2003 and 2003/2004), each tree received $0.5 \mathrm{~kg}$ NPK (20-10-20), $13 \mathrm{~kg}$ cattle manure, and $0.2 \mathrm{~kg}$ natural phosphate, and foliar application of $\mathrm{Ca}$ (10 sprayings with $\left.0.5 \% \mathrm{CaCl}_{2}\right), \mathrm{Zn}$, and $\mathrm{B}$. This orchard had been managed since planting with the use of chemical fertilizers, herbicides, insecticides and fungicides. The combined spraying of hydrogen cyanamide $(0.25 \%)$ plus mineral oil $(2 \%)$ was the established method to break dormancy at the end of September.

The organic orchard was planted in an area previously covered by native grassland. Soil acidity and nutrient deficiencies were corrected with $13 \mathrm{Mg} \mathrm{ha}^{-1}$ dolomite limestone, $300 \mathrm{~kg} \mathrm{ha}^{-1}$ triple superphosphate, $30 \mathrm{~kg} \mathrm{ha}^{-1}$ borax, and $80 \mathrm{~g}$ per plant of urea. In 1997, the soil was limed again with $5 \mathrm{Mg} \mathrm{ha}^{-1}$ dolomite limestone and $1 \mathrm{Mg} \mathrm{ha}^{-1}$ lime mud. In 1999, the orchard was converted from conventional to organic management with the use of animal manure and biological control of pests and diseases. For nutrition maintenance, the orchard received $5 \mathrm{Mg} \mathrm{ha}^{-1}$ horse manure, $50 \mathrm{~kg} \mathrm{ha}^{-1}$ Arad phosphate, $103 \mathrm{~kg} \mathrm{ha}^{-1}$ potassium sulfate, 10 foliar applications of calcium chloride $(0.25 \%)$, and 16 foliar applications of a biocompost ("Super Magro") per growing season. Weeds were controlled mechanically with mower, when vegetation in the cultivation line reached the lower branches of the trees (about three times per year). Diseases were controlled by foliar applications of lime sulfur $(0.7 \%)$ and Bordeaux mixture $(0.5-1 \%)$. Calcium nitrate $(1 \%)$ was sprayed, at the end of September for dormancy break.

The soil chemical characteristics of both orchards are shown in Table 1. Eighteen apple trees of each cultivar and management system were randomly selected and assessed for nutrition, flowering, fruit set, yield, and fruit quality during two growing seasons (2002/2003 and 2003/ 2004).

All flower clusters (at the pink stage of flower development, stage F2) on two representative limbs per tree were counted in 2002 and 2003. Flowering was expressed in terms of number of blossom clusters per $\mathrm{cm}^{2}$ of limb cross-sectional area (PCLA). Before fruit thinning at the end of October, all the persisting fruits on each tagged limb were counted. Fruit set was expressed in terms of number of persisting fruit PCLA and per blossom cluster (PBC).

Ten midshoot leaves from the current-season shoot and ten fruits per plant were collected 30 days before the start of fruit harvest and at harvest, and were assessed for $\mathrm{N}, \mathrm{K}, \mathrm{Ca}$, and $\mathrm{Mg}$ both years. The fruit mineral composition was assessed for the entire fruit (flesh + skin). The dry leaves and the fresh fruit samples were digested with a mixture of sulfuric acid and hydrogen peroxide, as described by Adler \& Wilcox (1985). Nitrogen was quantified by steam distillation using semi-micro Kjeldahl equipment. Calcium and $\mathrm{Mg}$ were determined with an inductive coupled plasma spectrophotometer (ICP), and K with a flame emission photometer.

Fruits from each tagged limb per tree were harvested at maturity each year and assessed for yield (total fruit weight PLCA) and average fruit weight.

Samples of 20 fruits per tree were assessed for quality at the commercial harvest, in terms of skin background

Table 1. Soil chemical attributes of apple orchards under a conventional and an organic production system, at the depths $0-10 \mathrm{~cm}$ and $10-20 \mathrm{~cm}$.

\begin{tabular}{|c|c|c|c|c|c|c|}
\hline \multirow[t]{2}{*}{ Attribute } & \multicolumn{2}{|c|}{$0-10 \mathrm{~cm}$} & \multirow[t]{2}{*}{ Significance } & \multicolumn{2}{|c|}{$10-20 \mathrm{~cm}$} & \multirow[t]{2}{*}{ Significance } \\
\hline & Conventional & Organic & & Conventional & Organic & \\
\hline pH (water) & 6.5 & 6.1 & * & 6.8 & 5.8 & * \\
\hline $\mathrm{pH}\left(\mathrm{CaCl}_{2}\right)$ & 5.7 & 5.3 & ns & 6.0 & 5.1 & $*$ \\
\hline $\mathrm{N}^{(1)}\left(\mathrm{mg} \mathrm{kg}^{-1}\right)$ & 10.7 & 11.7 & ns & 9.0 & 3.6 & $*$ \\
\hline $\mathrm{P}^{(2)}\left(\mathrm{mg} \mathrm{kg}^{-1}\right)$ & 23.3 & 4.8 & $*$ & 8.3 & 2.0 & $*$ \\
\hline $\mathrm{K}\left(\mathrm{cmol}_{\mathrm{c}} \mathrm{dm}^{-3}\right)^{(3)}$ & 0.70 & 0.50 & $*$ & 0.37 & 0.28 & ns \\
\hline $\mathrm{Ca}\left(\mathrm{cmol}_{\mathrm{c}} \mathrm{dm}^{-3}\right)^{(3)}$ & 8.0 & 7.0 & $*$ & 7.4 & 5.0 & $*$ \\
\hline $\operatorname{Mg}\left(\mathrm{cmol}_{\mathrm{c}} \mathrm{dm}^{-3}\right)^{(3)}$ & 1.6 & 1.4 & ns & 1.5 & 1.1 & $*$ \\
\hline $\mathrm{H}+\mathrm{Al}\left(\mathrm{cmol}_{\mathrm{c}} \mathrm{dm}^{-3}\right)$ & 6.3 & 5.9 & ns & 5.5 & 6.6 & $*$ \\
\hline
\end{tabular}

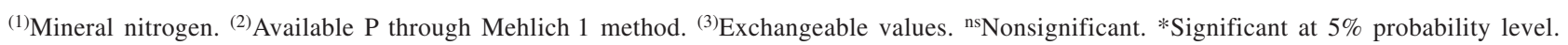


color, flesh firmness, soluble solids content, starch pattern index, titratable acidity (percentage of malic acid), fruit density, percentage of blush in the fruit skin, and russet severity. The incidence of moldy core and watercore was assessed in 'Fuji' only. Skin background color was assessed by means of a color chart, on a scale of 1 (darkgreen) to 8 (yellow-green). Flesh firmness was determined on two sides of each fruit, using a hand held penetrometer (Effegi FT 327, fitted with an $11.1 \mathrm{~mm}$ diameter head). Soluble solids content was determined with a hand refractometer on a composite juice sample collected during the pressure test. The starch pattern index (using the starch iodine test) was scored on a scale of 1 to 5 , where 1 indicates the least and 5 the most starch to sugar conversion. Titratable acidity from juice composite samples of five fruits was determined by titrating to an end point of $\mathrm{pH} 8.2$ with $0.1 \mathrm{~N} \mathrm{NaOH}$. Fruit density was assessed by the water displacement method. Blush in the fruit skin and russet severity were estimated subjectively. Incidence of moldy core and watercore was assessed in fruit sectioned transversally at the equator position and evaluated visually.

Fruits were evaluated at harvest for taste, flavor, and texture by $20-30$ non-trained panelists, who rated apple attributes on a scale from 0 to 5 (none to intense) (Meilgaard et al., 1999). The panelists were blocked, with the analysis of sensory scores following a completely randomized block design.

Data were averaged over the two growing seasons and then subjected to statistical analysis with the SAS (SAS Institute, 2002). Percentage data were transformed to $\operatorname{arc} \sin [(\mathrm{x}+5) / 100]^{1 / 2}$ before being submitted to the ANOVA.

\section{Results and Discussion}

In general, the soil chemical attributes of both orchards were adequate for apple growth (Table 1). The soil $\mathrm{pH}$ in both orchards was near the neutrality, which indicates adequate liming. The conventional orchard had consistently higher contents of $\mathrm{P}, \mathrm{Ca}, \mathrm{Mg}, \mathrm{K}$, and $\mathrm{N}$ in the soil than the organic one (Table 1). Only soil content of $\mathrm{P}$ in the organic orchard was slightly below the values considered adequate (Comissão de Química e Fertilidade do Solo, 2004).

The lower levels of $\mathrm{K}, \mathrm{Mg}$, and $\mathrm{N}$ in the leaves and fruit tissues of both cultivars in the organic orchard (Table 2) can be related to their lower contents in the soil (Table 1). Contents of $\mathrm{K}, \mathrm{Mg}$, and $\mathrm{N}$ in the leaves for the organic orchard are considered adequate for 'Royal Gala' and deficient for 'Fuji' (Comissão de Química e Fertilidade do Solo, 2004). Despite the lower soil availability of $\mathrm{Ca}$ in the organic orchard (Table 1), its content was reduced only in the leaves of 'Fuji' apples (Table 2).

Flowering (number of clusters PCLA assessed at full bloom) and fruit set (number of fruit PCLA) increased, while the number of fruit $\mathrm{PBC}$ reduced under organic management in 'Royal Gala' compared to the conventional system (Table 3 ). These variables were not affected by the management system in 'Fuji'. In 'Royal Gala', yield was not affected by the management system, but fruit from organic orchard had lower average weight. In 'Fuji', the organic production system reduced yield and fruit average weight.

Besides the lower soil supply of $\mathrm{P}, \mathrm{K}, \mathrm{Mg}, \mathrm{N}$, and $\mathrm{Ca}$, the disease control with lime sulfur in the organic orchard might have reduced leaf chlorophyll content, leaf mean area, and specific leaf area in both cultivars, leading to yield reduction in 'Fuji', but not in 'Royal Gala' (Table 3). Palmer et al. (2003) studied the effect of several fungicide programmes compatible with organic apple

Table 2. Leaf and fruit mineral composition of 'Royal Gala' and 'Fuji' apple trees from orchards under a conventional and an organic production system (values represent the average of two growing seasons - 2002/2003 and 2003/2004).

\begin{tabular}{|c|c|c|c|c|}
\hline Mineral & $\begin{array}{l}\text { Conventional } \\
\text { orchard }\end{array}$ & $\begin{array}{l}\text { Organic } \\
\text { orchard }\end{array}$ & Significance & CV (\%) \\
\hline & \multicolumn{4}{|c|}{$\begin{array}{l}\text { Royal Gala } \\
\text { Leaf }\left(\mathrm{g} \mathrm{kg}^{-1}\right)\end{array}$} \\
\hline $\mathrm{Ca}$ & 11.5 & 12.6 & ns & 20.9 \\
\hline K & 21.6 & 13.8 & $* * *$ & 30.5 \\
\hline $\mathrm{Mg}$ & 3.3 & 4.0 & $*$ & 19.7 \\
\hline \multirow[t]{2}{*}{$\mathrm{N}$} & 29.9 & 25.9 & $* *$ & 12.5 \\
\hline & \multicolumn{4}{|c|}{ Fruit $\left(\mathrm{mg} \mathrm{kg}^{-1}\right)$} \\
\hline $\mathrm{Ca}$ & 49.9 & 50.9 & ns & 17.1 \\
\hline K & $1,458.3$ & $1,066.1$ & $* * *$ & 22.4 \\
\hline $\mathrm{Mg}$ & 58.8 & 49.8 & $* * *$ & 12.3 \\
\hline \multirow[t]{2}{*}{$\mathrm{N}$} & 530.7 & 456.1 & $* * *$ & 12.6 \\
\hline & \multicolumn{4}{|c|}{$\begin{array}{c}\text { Fuji } \\
\text { Leaf }\left(\mathrm{g} \mathrm{kg}^{-1}\right)\end{array}$} \\
\hline $\mathrm{Ca}$ & 14.3 & 11.7 & $*$ & 24.6 \\
\hline $\mathrm{K}$ & 14.1 & 10.4 & $* * *$ & 22.5 \\
\hline $\mathrm{Mg}$ & 2.8 & 2.2 & $* *$ & 22.7 \\
\hline \multirow[t]{2}{*}{$\mathrm{N}$} & 26.1 & 19.1 & $* * *$ & 17.6 \\
\hline & \multicolumn{4}{|c|}{ Fruit $\left(\mathrm{mg} \mathrm{kg}^{-1}\right)$} \\
\hline $\mathrm{Ca}$ & 57.8 & 61.0 & $\mathrm{~ns}$ & 25.1 \\
\hline $\mathrm{K}$ & $1,323.0$ & $1,144.6$ & $* *$ & 19.5 \\
\hline $\mathrm{Mg}$ & 58.5 & 49.8 & $* * *$ & 11.5 \\
\hline $\mathrm{N}$ & 594.5 & 501.2 & $* * *$ & 15.3 \\
\hline
\end{tabular}

${ }^{\text {ns Nonsignificant. } *, * * \text { and } * * * \text { Significant at the } 0.05,0.01 \text { and } 0.001}$ probability levels, respectively. 
production, and reported significant reduction of leaf photosynthesis (up to almost 50\%) and fruit yield per tree (reduction of $12 \%$, largely as a result of decreased fruit number per tree rather than of mean fruit weight) by lime sulfur treatments, compared to the non sulfur treatments. Holb et al. (2003) and Jönsson (2007) also reported phytotoxicity of apple trees under organic management treated with lime sulfur to control scab [Venturia inaequalis (Cooke)], leading to reduced leaf size and reduced yield. The soluble sulfide component of lime sulfur is believed to be responsible for plant injury by reducing carbon dioxide assimilation, which appears to be a fundamental factor underlying the phytotoxic effects (Palmer et al., 2003).

The organic orchard received about 15 sprayings with lime sulfur $(0.7 \%)$ during the growing seasons for disease control, especially for the control of apple scab. In 'Fuji', this might have affected the photosynthetic activity in the leaves, which reduced yield and fruit average weight (Table 3). In 'Royal Gala', yield reduction might not have been expressed under organic management as a result of the expressive flowering and fruit set of the trees. In addition, manual fruit thinning of organic orchards was not as intensive as chemical thinning of conventional ones. Therefore, the higher initial crop load of 'Royal Gala' in

Table 3. Leaf chlorophyll content, leaf area, specific leaf area, flowering, fruit set, yield and fruit size of 'Royal Gala' and 'Fuji' apple trees from orchards under a conventional and an organic production system (values represent the average of two growing seasons - 2002/2003 and 2003/2004).

\begin{tabular}{|c|c|c|c|c|}
\hline Attribute & \multicolumn{4}{|c|}{ Conventional Organic Significance CV } \\
\hline & \multicolumn{4}{|c|}{ 'Royal Gala' } \\
\hline Leaf chlorophyll content $\left(\mu \mathrm{g} \mathrm{cm}^{-2}\right)$ & 18.5 & 14.7 & $* * *$ & 14.2 \\
\hline Leaf mean area $\left(\mathrm{cm}^{2}\right)$ & 35.8 & 25.3 & $* * *$ & 20.7 \\
\hline Specific leaf area $\left(\mathrm{cm}^{2} \mathrm{~g}^{-1}\right)$ & 107.7 & 128.7 & $* * *$ & 11.6 \\
\hline Number of clusters PCLA ${ }^{(1)}$ & 2.4 & 4.0 & $* * *$ & 33.9 \\
\hline Number of fruit PCLA & 8.3 & 12.3 & $* * *$ & 30.8 \\
\hline Number of fruit $\mathrm{PBC}^{(2)}$ & 4.4 & 3.4 & * & 30.6 \\
\hline Yield (kg of fruit PCLA) & 3.5 & 3.0 & ns & 35.4 \\
\hline \multirow[t]{2}{*}{ Fruit average weight $(\mathrm{g})$} & 118.3 & 83.3 & $* * *$ & 22.6 \\
\hline & & 'Fuji' & & \\
\hline Leaf chlorophyll content $\left(\mu \mathrm{g} \mathrm{cm}^{-2}\right)$ & 15.7 & 12.4 & $* * *$ & 14.9 \\
\hline Leaf mean area $\left(\mathrm{cm}^{2}\right)$ & 31.3 & 25.3 & $* * *$ & 15.6 \\
\hline Specific leaf area $\left(\mathrm{cm}^{2} \mathrm{~g}^{-1}\right)$ & 116.7 & 124.7 & $*$ & 9.5 \\
\hline Number of clusters PCLA & 2.4 & 2.4 & ns & 25.5 \\
\hline Number of fruit PCLA & 7.0 & 7.2 & ns & 28.1 \\
\hline Number of fruit PBC & 3.2 & 3.3 & ns & 31.6 \\
\hline Yield (kg of fruit PCLA) & 3.7 & 2.8 & $* *$ & 33.3 \\
\hline Fruit average weight (g) & 135.4 & 91.5 & $* * *$ & 22.8 \\
\hline
\end{tabular}

(1)PCLA: per square centimeter of limb cross-sectional area. ${ }^{(2)} \mathrm{PBC}$ : per

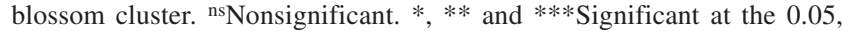
0.01 and 0.001 probability levels, respectively. the organic orchard might have been adjusted by natural fruit drop after fruit thinning, as a result of reduced carbon assimilation in the leaves caused by lime sulfur spraying. This possible compensation was not verified in 'Fuji' from organic orchard as a result of equivalent fruit sets between management systems, which led to a more substantial reduction of yield and fruit size under organic management.

Organic fruit of both cultivars had higher flesh firmness and higher soluble solids content at harvest than conventional fruit (Table 4), as reported by DeEll \& Prange (1992), Reganold et al. (2001), Weibel et al. (2004) and Peck et al. (2006). Fruit of both cultivars from the organic orchard had higher density, a more yellowish skin background color, and higher percentage of blush in the fruit skin than fruit from the conventional orchard. 'Royal Gala' fruit from organic orchard had lower titratable acidity than fruit from conventional orchard.

Table 4. Fruit quality of 'Royal Gala' and 'Fuji' apples under a conventional and an organic production system at the commercial harvest maturity (values represent the average of two growing seasons - 2002/2003 and 2003/2004).

\begin{tabular}{|c|c|c|c|c|}
\hline Fruit quality attribute & $\begin{array}{c}\text { Conventional } \\
\text { orchard }\end{array}$ & $\begin{array}{l}\text { Organic } \\
\text { orchard }\end{array}$ & Significance & $\begin{array}{l}\text { CV } \\
(\%)\end{array}$ \\
\hline & \multicolumn{4}{|c|}{ 'Royal Gala' } \\
\hline Flesh firmness $(\mathrm{N})$ & 95.3 & 100.6 & $* *$ & 6.0 \\
\hline Soluble solids content $\left({ }^{\circ} \mathrm{Brix}\right)$ & 11.3 & 12.0 & $* *$ & 6.3 \\
\hline Starch index $(1-5)$ & 2.6 & 2.5 & $\mathrm{~ns}$ & 31.3 \\
\hline Titratable acidity $(\%)$ & 0.5 & 0.4 & $*$ & 15.0 \\
\hline Skin background color $(1-8)$ & 4.7 & 5.5 & $* *$ & 15.0 \\
\hline Blush in the fruit skin $(\%)$ & 76.0 & 82.7 & $* *$ & 8.4 \\
\hline Fruit density $\left(\mathrm{g} \mathrm{cm}^{-3}\right)$ & 0.867 & 0.886 & $* * *$ & 1.8 \\
\hline Russet severity $\left(\mathrm{cm}^{2}\right.$ fruit $\left.{ }^{-1}\right)$ & 2.3 & 4.8 & $* * *$ & 46.4 \\
\hline Taste $(1-5)$ & 3.2 & 3.1 & ns & 31.2 \\
\hline Flavor (1-5) & 2.8 & 3.1 & ns & 33.8 \\
\hline \multirow[t]{2}{*}{ Texture $(1-5)$} & 3.7 & 3.8 & ns & 26.7 \\
\hline & & 'Fuji' & & \\
\hline Flesh firmness $(\mathrm{N})$ & 81.2 & 88.0 & $* * *$ & 5.3 \\
\hline Soluble solids content $\left({ }^{\circ}\right.$ Brix $)$ & 12.8 & 13.4 & $* *$ & 4.4 \\
\hline Starch index $(1-5)$ & 3.7 & 3.8 & ns & 9.2 \\
\hline Titratable acidity $(\%)$ & 0.4 & 0.4 & ns & 8.1 \\
\hline Skin background color $(1-8)$ & 4.1 & 5.1 & $* * *$ & 12.8 \\
\hline Blush in the fruit skin $(\%)$ & 82.2 & 91.1 & $* * *$ & 5.4 \\
\hline Fruit density $\left(\mathrm{g} \mathrm{cm}^{-3}\right)$ & 0.873 & 0.889 & $* * *$ & 1.4 \\
\hline Russet severity $\left(\mathrm{cm}^{2}\right.$ fruit $\left.{ }^{-1}\right)$ & 5.2 & 6.9 & $* * *$ & 26.7 \\
\hline Watercore $(\%)$ & 50.6 & 40.1 & $* *$ & 13.4 \\
\hline Moldy core $(\%)$ & 5.4 & 21.9 & $* * *$ & 43.8 \\
\hline Taste $(1-5)$ & 3.5 & 3.3 & ns & 22.7 \\
\hline Flavor $(1-5)$ & 3.2 & 2.9 & ns & 22.6 \\
\hline Texture $(1-5)$ & 3.8 & 3.7 & ns & 16.3 \\
\hline
\end{tabular}

${ }^{\text {ns Nonsignificant. } *, * * \text { and } * * * \text { Significant at the } 0.05,0.01 \text { and } 0.001}$ probability levels, respectively. 
Plant nutrition influences fruit quality. Fruit size depends on plant nutrition, which also remarkably influences postharvest quality. 'Royal Gala' and 'Fuji' apples grown organically had lower average weight (Table 3), possibly due to smaller cells and less intercellular spaces, reflecting nutritional status of N, K, and $\mathrm{Mg}$ (Table 2) and plant physiology, leading to a higher fruit density (Table 4). Denser fruit tend to have reduced air-filled spaces possibly associated with higher flesh firmness at harvest in organic apples of both cultivars (Table 4).

Calcium and $\mathrm{N}$ have pronounced effects on fruit quality in general, and on firmness in particular (Johnston et al., 2002). Increased $\mathrm{N}$ status in fruit trees is known to increase fruit size, but along with lower $\mathrm{Ca}$ concentration, it delays color development, reduces fruit firmness, and increases postharvest disorders and decay (DeEll \& Prange, 1992, 1993). There was no significant effect of production system on Ca concentration in the fruit of 'Royal Gala' or 'Fuji' (Table 2). However, N:Ca ratio in the fruit was lower in organically produced fruit (8.2 for 'Fuji' and 9.0 for 'Royal Gala') than for conventional apples (10.3 for 'Fuji' and 10.6 for 'Royal Gala'), mainly reflecting differences of $\mathrm{N}$ concentration. This might have resulted in higher flesh firmness, more yellowish background color, and higher percentage of blush in the fruit skin in organic than in conventional fruits in both cultivars. Peck et al. (2006) reported lower N:Ca ratio in fruit and, therefore, higher flesh firmness in organic than in conventional and integrated apples.

Some authors reported equal or better overall acceptability (sweeter and less tart fruits), firmness, and texture for apples from organic than conventional orchard (Reganold et al., 2001; Weibel et al., 2004; Peck et al., 2006). Despite differences in terms of physicochemical quality of 'Royal Gala' and 'Fuji' apples between production systems, the untrained sensory panelists detected no differences in terms of taste, flavor and texture between organic and conventional fruits (Table 4). These results are consistent with those of DeEll \& Prange (1992) showing that trained sensory panelists were unable to detect difference between organic and conventional apples. Also, Róth et al. (2007) observed no significant difference in terms of aroma volatiles between apples from organic and integrated production systems.

For both cultivars, fruits from organic orchard had higher severity of russet (Table 4). This might be the result of phytotoxic effects of spraying on orchard under organic management with lime sulfur and Bordeaux mixture (a copper containing fungicide) for disease control. In Netherlands, the treatment of organic apple orchards with lime sulfur increased russet and, consequently, reduced the percentage of first class fruits (Holb et al., 2003). Copper sprays have frequently been found to induce russet, even where such sprays were restricted to early season applications up until tight cluster. In New Zealand, a significant increase in the percentage of rejected fruits was reported as a result of increased russet incidence on apples from organic orchard treated with copper containing fungicides (Palmer et al., 2003). The effect of copper on russet and its build up in the soil makes its long-term use questionable (Palmer et al., 2003; Li et al., 2005).

Diseases represent a major problem in organic apple orchards (DeEll \& Prange, 1992, 1993; Holb et al., 2003; Palmer et al., 2003; Cesa et al., 2006). 'Fuji' produced organically had higher incidence of moldy core than fruits from the conventional orchard (Table 4). This may reflect a higher pathogen pressure (Jönsson, 2007) and a lower mineral supply (Peck et al., 2006) in the organic orchard. The incidence of brown rot, bull's-eye rot and decayed fruit due to unknown fungi were higher in organic than in conventional apples (Jönsson, 2007). DeEll \& Prange $(1992,1993)$ also reported reduced marketability, as a result of higher incidence of storage rots and apple scab, for organically grown apples.

'Fuji' apples produced organically had lower incidence of watercore (Table 4). Increased watercore severity in 'Fuji' is associated to higher internal ethylene concentration, especially in later harvested fruit (Bowen \& Watkins, 1997). Preharvest spraying of apple trees with aminoethoxyvinylglycine (AVG), an inhibitor of ethylene synthesis, delays fruit maturity and reduces both internal ethylene concentration and watercore in the fruit at harvest (Drake et al., 2005). Peck et al. (2006) report lower internal ethylene concentration at harvest and after three months of regular atmosphere storage in organic than in conventional apples. Both $\mathrm{N}$ concentration and the ratio $\mathrm{N}: \mathrm{Ca}$ in apple fruit are positively correlated to ethylene production (Johnston et al., 2002). The lower incidence of watercore in 'Fuji' produced organically (Table 4) may reflect a reduced internal ethylene concentration, related to the lower ratio of $\mathrm{N}: \mathrm{Ca}$ in the fruit. 
The results confirm research published by several authors, reporting overall better physicochemical quality (DeEll \& Prange, 1992; Reganold et al., 2001; Weibel et al., 2004; Peck et al., 2006), and higher (10-15\%) antioxidant activity (Peck et al., 2006), in organic than in conventional apples, which might not be always accompanied by a better perception of taste and flavor in organic fruit (DeEll \& Prange, 1992; Róth et al., 2007). Jönsson (2007) and Róth et al. (2007) reported no significant differences in fruit quality between apples from organic and integrated orchards, neither at harvest nor after storage. Divergences between results reported by different authors may reflect distinctive seasons and sites (related to variable cropping and climatic factors) interacting with orchard management systems and nutrition supply under the experimental conditions of each study (Reganold et al., 2001).

Pests and pathogens can significantly reduce yield, fruit quality and premium price of apples under organic production (DeEll \& Prange, 1993; Cesa et al., 2006). Therefore, successful pest and pathogens control is required for organic apple production to achieve comparable or better returns than conventional and integrated production systems. Development of cultivars resistant to diseases and pests and well adapted in Southern Brazil (such as cultivar Catarina, resistant to apple scab) will be highly valuable to encourage organic apple production. In addition, the adoption of cultural practices to reduce primary inoculum, such as the removal of cultural waste (removal of leaves and branches/shoots after pruning), the establishment of full and balanced nutrition, and the use of organically certified plant protection products and flower/fruitlet thinners are important aspects to consider for the profitability of organic apple production.

\section{Conclusions}

1. In comparison to the conventional orchard the organic apple orchard reduced soil supply of nutrients, leading to a reduced concentration of $\mathrm{K}, \mathrm{Mg}$, and $\mathrm{N}$ in the leaves and fruits of 'Royal Gala' and 'Fuji'.

2. In comparison to the conventional orchard the organic apple orchard reduced fruit average weight in 'Royal Gala' and 'Fuji' and reduced yield in 'Fuji'.

3 . The organic apple orchard had fruit with a more yellowish skin background color, higher percentage of blush in the skin, higher soluble solids content, higher density, and higher flesh firmness in 'Royal Gala' and 'Fuji'.

4. The organic apple orchard had fruit with higher incidence of moldy core and lower incidence of watercore in 'Fuji', and with higher severity of russet in 'Royal Gala' and 'Fuji'.

\section{Acknowledgements}

To the Financiadora de Estudos e Projetos, Conselho Nacional de Desenvolvimento Científico e Tecnológico and the Fundação de Ciência e Tecnologia de Santa Catarina, for financial support.

\section{References}

ADLER, P.R.; WILCOX, G.E. Rapid perchloric acid digestion methods for analysis of major elements in plant tissue. Communications in Soil Science and Plant Analysis, v.16, p.1153-1163, 1985.

BOWEN, J.H.; WATKINS, C.B. Fruit maturity, carbohydrate and mineral content relationships with watercore in 'Fuji' apples. Postharvest Biology and Technology, v.11, p.31-38, 1997.

CESA, L.P.; JESUS JÚNIOR, W.C.; BOGO, A.; LAZAROTO, A.; SILVA, A.; AMARANTE, C.V.T. Temporal analysis of apple scab in 'Royal Gala' and 'Fuji' under conventional and organic production systems. Fitopatologia Brasileira, v.31, p.585-591, 2006.

COMISSÃO DE QUÍMICA E FERTILIDADE DO SOLO. Sociedade Brasileira de Ciência do Solo. Manual de adubação e calagem para os estados do RS e SC. 10.ed. Porto Alegre: SBCS, 2004. 400p.

DeELL, J.R.; PRANGE, R.K. Postharvest physiological disorders, diseases and mineral concentrations of organically and conventionally grown 'McIntosh' and 'Cortland' apples. Canadian Journal of Plant Science, v.73, p.223-230, 1993.

DeELL, J.R.; PRANGE, R.K. Postharvest quality and sensory attributes of organically and conventionally grown apples. HortScience, v.27, p.1096-1099, 1992.

DRAKE, S.R.; EISELE, T.A.; DRAKE, M.A.; ELFVING, D.C.; DRAKE, S.L.; VISSER, D.B. The influence of aminoethoxyvinylglycine and ethephon on objective and sensory quality of 'Delicious' apples and apple juice at harvest and after storage. HortScience, v.40, p.2102-2108, 2005.

EPAGRI. Síntese anual da agricultura de Santa Catarina: 2005/ 2006. Florianópolis: Epagri, 2006. 294p.

GLOVER, J.D.; REGANOLD, J.P.; ANDREWS, P.K. Systematic method for rating soil quality of conventional, organic, and integrated apple orchards in Washington State. Agriculture, Ecosystems and Environment, v.80, p.29-45, 2000.

HOLB, I.J.; JONG, P.F. de; HEIJNE, B. Efficacy and phytotoxicity of lime sulphur in organic apple production. Annals of Applied Biology, v.142, p.225-233, 2003. 
JOHnston, J.W.; HEWETT, E.W.; HERTOG, M.L.A.T.M. Postharvest softening of apple (Malus domestica) fruit: a review. New Zealand Journal of Crop and Horticultural Science, v.30, p.145-160, 2002.

JÖNSSON, Å.H. Organic apple production in Sweden: cultivation and cultivars. 2007. 33p. Thesis (Ph.D.) - Swedish University of Agricultural Sciences, Balsgård.

LI, W.; ZHANG, M.; SHU, H. Distribution and fractionation of copper in soils of apple orchards. Environmental Science and Pollution Research, v.12, p.168-172, 2005.

MALUCHE-BARETTA, C.R.D.; AMARANTE, C.V.T. do; KLAUBERG FILHO, O. Multivariate analysis of soil attributes of apple orchards under conventional and organic production systems. Pesquisa Agropecuária Brasileira, v.41, p.1531-1539, 2006.

McARTNEY, S.J.; WALKER, J.T.S. Current situation and future challenges facing the production and marketing of organic fruit in Oceania. Acta Horticulturae, v.638, p.387-396, 2004.

MEILGAARD, M.; CIVILlE, G.V.; CARR, B.T. Sensory evaluation techniques. $3^{\text {rd }}$ ed. Boca Raton: CRC Press, 1999. 416p.

OLTRAMARI,A.C.;ZOLDAN,P.;ALTMANN, R. Agricultura orgânica em Santa Catarina. Florianópolis: Instituto CEPA, 2002. 55p.

PALMER, J.W.; DAVIES, S.B.; SHAW, P.W.; WÜNSCHE, J.N. Growth and fruit quality of 'Braeburn' apple (Malus domestica) trees as influenced by fungicide programmes suitable for organic production. New Zealand Journal of Crop and Horticultural Science, v.31, p.169-177, 2003.
PECK, G.M.; ANDREWS, P.K.; REGANOLD, J.P.; FELLMAN, J.K. Apple orchard productivity and fruit quality under organic, conventional, and integrated management. HortScience, v.41, p.99107, 2006.

PECK, G.M.; ANDREWS, P.K.; RICHTER, C.; REGANOLD, J.P. Internationalization of the organic fruit market: the case of Washington State's organic apple exports to the European Union. Renewable Agriculture and Food Systems, v.20, p.101-112, 2005.

REGANOLD, J.P.; GLOVER, J.D.; ANDREWS, P.K.; HINMAN, H.R. Sustainability of three apple production systems. Nature, v.410, p.926-930, 2001.

RÓTH, E.; BERNA, A.; BEULLENS, K.; LAMMERTYN, J.; SCHENK, A.; NICOLAÏ, B. Postharvest quality of integrated and organically produced apple fruit. Postharvest Biology and Technology, v.45, p.11-19, 2007.

SAS INSTITUTE. Getting started with the SAS learning edition. Cary: SAS, 2002. 200p.

VOGELER, I.; CICHOTA, R.; SIVAKUMARAN, S.; DEURER, M.; McIVOR, I. Soil assessment of apple orchards under conventional and organic management. Australian Journal of Soil Research, v.44, p.745-752, 2006.

WEIBEL, F.; WIDMER, F.; HUSISTEIN, A. Comparison of production systems: integrated and organic apple production. Part III: Inner quality: composition and sensory. Obst-und Weinbau, v.140, p.10-13, 2004.

Received in October 30, 2007 and accepted in February 28, 2008 